\title{
Understanding healthy body and dieting of youth athletes among Javanese Muslim parents
}

\author{
1,2, ${ }^{*}$ Dewi, N.S., ${ }^{2}$ Jittanoon, P. and ${ }^{2}$ Wiroonpanich, W. \\ ${ }^{I}$ Department of Nursing, Faculty of Medicine, Universitas Diponegoro, Semarang, Central Java, Indonesia \\ ${ }^{2}$ Faculty of Nursing, Prince of Songkla University, Hat Yai, Songkhla, Thailand
}

\author{
Article history: \\ Received: 29 December 2019 \\ Received in revised form: 7 \\ January 2020 \\ Accepted: 3 February 2020 \\ Available Online: 30 May \\ 2020
}

Keywords:

Healthy body,

Healthy diet,

Javanese Muslim parents,

Youth athletes,

Indonesia

\section{DOI:}

https://doi.org/10.26656/fr.2017.4(S3).S01

\begin{abstract}
This phenomenological research is aimed to explore the perspectives of parents about the healthy body and dietary requirements for youth athletes. Data were obtained from the Javanese Muslim parents who have children who are youth athletes in two provinces of Indonesia, Central Java and East Java. Interviews were conducted with nine participants using a semi-structured guideline. Data analysis used Giorgi phenomenological approach. This study found various perceptions about the healthy body and dieting of youth athletes. Parents perceived a healthy body could be shown by no injury and the ability to reach the targets in either training or competing. As Muslims, they emphasized the importance of providing halal food because the food that enters the body would affect bodily functions. They stressed the importance of supplements to replace the lack of nutrients in the body and increased water intake. However, they expressed confusion in the composition, portion and frequency of nutrition for athletes. The limited understanding of nutrition for athletes urged parents to value the importance of advice from health workers related to maintaining athletes' performance and the nutrition they needed. The results of this study indicated the need to improve parents' knowledge and skills regarding nutrition management to maintain athletes' performance by considering Islamic laws.
\end{abstract}

\section{Introduction}

Being an athlete at a young age provides an additional burden on teenagers. They must be able to keep a balance between roles as students and as athletes. From an early age, they are pressured to become champions in every national or international competition that they participate in. They have to practice consistently at high intensity from childhood to prepare them physically well for competition (Gould and Whitley, 2009; Manzi et al., 2010; Scott et al., 2013). To support their intensive training, a healthy body must be observed.

Parents are some of those adults who have a main contribution to the care of young talented children (Wiersma and Fifer, 2008; Wu, 2008). They make extra efforts to meet the needs of youth athletes compared to parents who have children of average ability. They must ensure and encourage the achievements of their children and help them fulfill their potential to reach the highest level of their ability ( $\mathrm{Wu}, 2008$ ). Parents are also the main source of support in helping in the coping process during the end of season injury and in maintaining a healthy body (Wuerth et al., 2004).
Based on this phenomenon, the perspective of parents about the healthy body and dietary requirements for athletes needs to be explored. Most of the sport studies in Indonesia have been explored quantitatively about the dietary or healthy status only (Lestari and Amin, 2019; Rachmad et al., 2016; Siregar and Dani, 2019). Thus, this research was needed to be able to explore new understanding regarding the healthy body and dietary requirements for youth athletes through the perspective of Javanese Muslim parents.

\section{Materials and methods}

The phenomenological descriptive methodology from Giorgi was used to obtain the understanding of healthy body and nutrition of youth athletes among Javanese Muslim parents from East and Central Java, Indonesia. Purposive and snowball techniques were chosen to obtain data from nine participants. The participants were biological/adopted parents who had a youth athlete studying in college or university. The description of the participant's characteristics is presented in the Table 1.

The researchers collected data through in-depth 
Table 1. The numbers of parents and youths by demographic characteristics $(\mathrm{N}=9)$

\begin{tabular}{|c|c|c|c|c|c|c|c|}
\hline \multirow{2}{*}{ Participant } & \multicolumn{5}{|c|}{ Parents } & \multicolumn{2}{|c|}{ Youths } \\
\hline & Age & Gender & Job & Income level & Education level & Talent & Gender \\
\hline 1 & 58 & Male & Teacher & High & Bachelor & Table tennis & Male \\
\hline 2 & 61 & Male & Retired & Middle & Bachelor & Table tennis & Male \\
\hline 3 & 58 & Male & Teacher & High & Bachelor & Football & Female \\
\hline 4 & 52 & Male & Teacher & Middle & Bachelor & Softball & Female \\
\hline 5 & 58 & Male & Army retired & High & High school & Table tennis & Male \\
\hline 6 & 55 & Male & Public officer & High & Bachelor & Table tennis & Female \\
\hline 7 & 50 & Male & Self employee & Middle & High school & Table tennis & Female \\
\hline 8 & 50 & Male & Self employee & Low & Elementary school & Pencak silat & Male \\
\hline 9 & 57 & Male & Public officer & Middle & Bachelor & Kempo & Female \\
\hline
\end{tabular}

interviews and field notes. All interviews were conducted by the principal researcher. Semi-structured interviews and open-ended questions were conducted to collect data. Interviews were carried out twice, ranging from 30 to $90 \mathrm{mins}$ at the participants' homes, at different times. All interviews were recorded as agreed upon by participants. During the interview process, none of the parents asked to turn off the recorder. They allowed the researcher to complete interviews without a time limit.

During the interview, the researcher used a mixture of Javanese and Indonesian languages. To gain an understanding of parental experience, interviews usually began with general questions focusing on the research topic (Seidman, 2006). The researcher followed general interview guidelines. Upon exploring parental experiences in the interviews, the researcher clarified unclear statements to ensure that the researcher's understanding of such experiences was consistent with the parent's experiences. To gather deeper information, in each primary interview question, the researcher followed up by using probing questions about the issues raised during the response. During the interview, the researcher also took field notes to improve the quality of data obtained in the study.

Phenomenological descriptive method from Giorgi was carried out to analyze the data. Giorgi developed this method to discover the true essence of the phenomena. According to Giorgi's approach, the researcher tries to understand the meaning of the description as presented. Giorgi's analytic process consists of five steps: reading to feel the whole; determining the unit meaning; applying sensitive expressions into sensitive expressions (meaning units); synthesizing meaning units that are transformed into consistent statements; and the final synthesis of information into consistent statements (Broome, 2011).

This study was approved by the Research Ethics Committee, Faculty of Nursing, Prince of Songkla
University, Thailand (no. 2017 NSt - Qn 029). Informed consent was obtained both verbally and in writing from the parents. All parents were given information to ensure their understanding that participation was voluntary and that they could withdraw from the study at any time without penalty. In the interviews, the comfort of participants was considered as a first priority. Interviews were stopped and rescheduled if parents requested. The informed consent document consists of four main elements; ethical consideration regarding the research objectives; what would happen during the interview; potential benefits; and all risks that might arise in connection with the interview process. The researcher gave parents the opportunity to ask anything related to the information contained in the agreement and to decide whether to participate or not in this study.

\section{Results and discussion}

\subsection{The meaning of a healthy body}

All parents believe that having a healthy body is an asset for athletes to support their careers. They see that athletic competition is very tight and the athletes must be able to withstand the pressure around them. A healthy body that maintains safety is a key determinant of the success of gifted youth in competitions (Raysmith and Drew, 2016).

Parents perceive a healthy body as a condition of no injury and one that is able to reach the targets arranged in training or competition. As the father of a young female football athlete (P3) mentioned, "If she is not sick or injured, her performance would be very good... so she can reach the target during training or when competing as arranged...." Young athletes have high-risk moments for injury both in training and competing (Lloyd et al., 2015). Injury or illness results in loss of training, which further contributes to a decrease in bodily function (Lloyd et al., 2015; Raysmith and Drew, 2016). 


\subsection{Managing diets}

Maintaining a healthy body is the main determinant of the success of talented youth in the competition (Raysmith and Drew, 2016). One of the efforts to maintain a healthy body is by managing a proper diet for athletes. In this study, managing diets consists of providing multivitamins, eating fresh food, following the Islamic diet, serving empat sehat lima sempurna, managing nutrition by experts, as well as confusing nutrition management at home.

\subsection{Providing multivitamins}

All parents agree that youth athletes look exhausted after completing their competition or training. They consider giving multivitamins important because fatigue will increase the risk of injury or pain in athletes. They believe that giving multivitamins will improve body performance so the athlete does not get tired easily. Some parents give multivitamins as a substitute food for the athlete's body. Even if their children have a lack of appetite, they will be helped by multivitamins. A total of $66 \%$ of parents give multivitamins to help athletes to become energetic and to prevent fainting during their training or competing. However, all parent perceived that drinking water is the best way to replace the loss of body hydration. They suggested the children increase water intake, particularly during their training or competing. Macronutrients provide a source of energy needed to stimulate the body, maintain cell hydration, and provide the body's structure to do the activity. Micronutrients enable the use of macronutrients for all physiological processes (Lukaski, 2004), as the father of a young male table tennis athlete said,

"I usually give him multivitamins every day. These help him become energetic, tireless and prevent him from fainting ... When my child does not take this multivitamin; his body will be weak and will break down ... "( (P1)

\subsection{Eating fresh food}

Parents believe that eating fresh fruit or vegetables are a healthy snack for the body compared to processed or frozen foods. Parents feel that athletes need to focus during training or competition. Thus, some parents always serve fresh fruit or vegetables as a family daily meal. They say that fresh foods are easily obtained at traditional markets. They do not trust fresh fruits or vegetables sold in supermarkets. They consider vegetables or fruits in supermarkets as being sprayed with chemicals to keep them fresh. Some parents even have vegetable or fruit plants in their homes, and they take vegetables or fruit from their own garden for family consumption. They assume that vegetables and fruit from their own gardens do not contain chemicals because they use the organic fertilizer made from green plants and animals. So parents feel safer upon feeding these vegetables and fruit to their young athlete. As the father of a young female softball athlete (P4) said:

"I never give processed food. This is not good for the body because it contains toxins. Fresh foods are safer than processed ones ... Eating fresh fruits and vegetables as a snack is healthier for the brain."

"My family consumes vegetables and fruit from our own garden ... They are healthier because we do not use chemicals ... we only use organic fertilizer made from green manure and the dirt of the animals." (P7) (Father of a young female table tennis athlete)

\subsection{Following the Islamic diet}

Parents believe that every good conduct must begin with asking for God's blessing. It motivates parents to remind their children to start eating with prayer, with the hope that the food can strengthen the performance of the youth athletes' bodily functions. As the father of a young male pencak silat (P8) said,

"Before breakfast, I always ask one of my children to pray. I believe that if we always remember prayer before and after eating, the food we eat will benefit us for our bodies (barakah)."

In addition, all parents do not provide food or drink or anything that is prohibited by Islamic law. They believe that halal food (permitted by Islamic law) benefits their bodies; conversely, when they eat or drink haram food (prohibited by Islamic law), it negatively impacts on their bodies. A total of $44 \%$ of the parents also mention that everything that is consumed in excessive amounts is also avoided and that also is included in the haram food. As the father of a young male table tennis athlete (P2) said:“... But I never give excessive multivitamins, it is dangerous for his body ... it is haram."

One parent (a father of a young female kempo athlete) mentioned that his family never serves fish and meat at the same time. He argues that it will make the body get sick. Everything that comes from the sea must be eaten separately with any food containing meat (chicken, beef). He also reminds his children to drink in a sitting position; he warns them if they forget and drink in a standing position. He believes that drinking while standing damages the kidney quickly. He also regularly gives honey and some herbs (habatus saudah) to increase stamina. 
3.6 Serving Empat Sehat Lima Sempurna (four healthy five perfect meals)

About $55 \%$ of youth athletes live with their parents. In presenting the nutrition, some middle-to-upper class parents try to provide a full meal containing empat Sehat Lima Sempurna menu (Indonesian proverb to explain a healthy diet that covers the body's main needs: carbohydrates, proteins, fats, vitamins and minerals) every day. Daily food consumption that contains empat Sehat Lima Sempurna positively influences the athlete's energy fitness (i.e. aerobic capacity and anaerobic capacity) and muscle fitness (i.e. strength, endurance, speed, strength, flexibility, balance, and dexterity) (Nurhidayah and Graha, 2017). Parents claim that such a menu is the best to support the activities of youth athletes. Parents with middle to upper economic levels tend to serve meat (i.e. beef, chicken, and lamb) as a side dish to increase their children's stamina. They perceived that a good diet supports intensive exercise, prevents the risk of injury, and is adjusted to training stimuli. Foods that meet proportional calorie requirements place athletes in a healthy condition and at the optimal performance (Arsani, 2014). The father of a young female table tennis athlete (P6) said:

"Every time she comes home from training, my daughter looks tired...I asked my wife to prepare empat sehat lima sempurna foods. I think this diet is good for athletes' stamina. "

However, $33 \%$ of parents say that there is no special food that they serve to youth athletes; their menu is the same as other family members. They believed that this food is enough to support the activities of youth athletes.

\subsection{Managing nutrition by experts}

Parents who have youth athletes living in athletes' dorms explain different experiences. The parents state that this talent club has several health experts who serve and manage the appearance and nutrition of athletes. They ensure that the club has strived to meet the nutritional balance of talented youth. Two parents mentioned that the role of nutritionists in managing the nutrition of their talented youth is very important. They trust the nutritionists to look after the youth's health. The roles of sports nutritionists include nutrition and diet assessments, evaluation of nutritional supplements, assessment of fluid intake, weight management, and counseling for energy and nutritional needs and for optimal food choices (Burns et al., 2004).

“... One that takes international sports schools provides many facilities so that their students maintain their health ... This school also pays attention to nutrition intake. This school has nutritionists to manage the nutritional supply of its students. They also have physical trainers to maintain the healthy body performance of their students ... "(P5) (Father of a young male table tennis athlete)

\subsection{Confusing nutrition management at home}

Exactly $100 \%$ of the parents are still confused about the composition, proportions and ideal frequency that can support the performance of youth athletes to the fullest. Thus, some of them only provide extra portions and a higher frequency of food for their gifted youth, as compared to other family members. Therefore, they expressed the need for information from health workers to maintain the performance of their children in their homes.

Although parents who have teenage athletes living in athletes' dorms say that the nutrition of their youth is of concern and is followed by the nutritionist; they also complained about the lack of information from the nutrition-related club that has to be given to their children when they are at the home. They reveal that often their children do not control their eating patterns which caused them to gain weight, even though as athletes, they must maintain a strict weight. As the parent of a young male pencak silat athlete (P8) said:

"Every time he comes home, he eats as much as he can so that his weight rises ... He has to maintain his weight because in his class there are limits to maximum weight ... so I only suggest that he reduces the portion of food that is high in fat and sugar, fasts, and exercises."

\section{Conclusion}

The results of this study gave an understanding of parents' lack of information on dietary management for youth athletes. Therefore, it is very important for health workers (nurses, nutritionists, doctors) to develop nutritional counseling for parents so that adolescents can meet their nutritional intake in consideration of the Islamic laws.

\section{Conflict of Interest}

There are no potential conflicts of interest relevant to this article to be reported.

\section{Acknowledgments}

The authors hereby express their gratitude to all the parents who participated in this study. We also thank the Directorate of Higher Education, Ministry of Research and Technology, Government of Indonesia for providing scholarships to the principal investigator and thank you to the Graduate School, Prince of Songkla University for 
supporting this study.

\section{References}

Arsani, N.L.K.A. (2014). Manajemen gizi atlet cabang olahraga unggulan di Kabupaten Buleleng [The nutrition management of elite sport athletes at Buleleng district]. Jurnal Sains dan Teknologi, 3(1), 275-287. undiksha.v3i1.2906

Broome, R.E. (2011). Descriptive phenomenological psychological method: An example of a methodology section from doctoral dissertation. San Fransico, USA: Saybrook University, $\mathrm{PhD}$ Dissertation.

Burns, R.D., Schiller, M.R., Merrick, M.A. and Wolf, K.N. (2004). Intercollegiate student athlete use of nutritional supplements and the role of athletic trainers and dietitians in nutrition counseling. Journal of the American Dietetic Association, 104 (2), 246-249. https://doi.org/10.1016/ j.jada.2003.11.013

Gould, D. and Whitley, M.A. (2009). Sources and consequences of athletic burnout among college athletes. Journal of Intercollegiate Sport, 2(1), 1630. https://doi.org/10.1123/jis.2.1.16

Lestari, Y.N.A. and Amin, N. (2019). Hubungan status gizi, tingkat kecukupan energi dan zat gizi dengan kecepatan pada atlet hockey kota Surabaya [The relationship among nutritional status, energy sufficiency's levels, nutrient status and speed on the hockey athletes at Surabaya District]. Sport and Nutrition Journal, 1(1), 19-26. https:// doi.org/10.15294/spnj.v1i1.31275

Lloyd, R.S., Oliver, J.L., Radnor, J.M., Rhodes, B.C., Faigenbaum, A.D. and Myer, G.D. (2015). Relationships between functional movement screen scores, maturation and physical performance in young soccer players. Journal of Sports Sciences, 33 (1), 11-19. https:// doi.org/10.1080/02640414.2014.918642

Lukaski, H.C. (2004). Vitamin and mineral status: Effects on physical performance. Nutrition, 20(7-8), 632-644. https://doi.org/10.1016/j.nut.2004.04.001

Manzi, V., D'ottavio, S., Impellizzeri, F.M., Chaouachi, A., Chamari, K. and Castagna, C. (2010). Profile of weekly training load in elite male professional basketball players. The Journal of Strength and Conditioning Research, 24(5), 1399-1406. https:// doi.org/10.1519/JSC.0b013e3181d7552a

Nurhidayah, D. and Graha, A.S. (2017). Profil kondisi fisik atlet unit kegiatan mahasiswa pencak silat Universitas Negeri Yogyakarta kategori tanding
[Profile of the physical condition of pencak silat athletes of the Yogyakarta State University in the duel category]. MEDIKORA, 16(1), 1-16.

Rachmad, Z.Y., Ratnawati, D.E. and Arwan, A. (2016). Optimasi komposisi makanan untuk atlet endurance menggunakan metode Particle Swarm Optimization [The optimization of food composition for athlete's endurance using the Particle Swarm Optimization Method]. Jurnal Teknologi Informasi dan Ilmu Komputer, 3(2), 103-109. https://doi.org/10.25126/ jtiik.201632203

Raysmith, B.P. and Drew, M.K. (2016). Performance success or failure is influenced by weeks lost to injury and illness in elite Australian track and field athletes: a 5-year prospective study. Journal of Science and Medicine in Sport, 19(10), 778-783. https://doi.org/10.1016/j.jsams.2015.12.515

Scott, B.R., Lockie, R.G., Knight, T.J., Clark, A.C. and Janse de Jonge, X.A.K. (2013). A Comparison of methods to quantify the in-season training load of professional soccer players. International Journal of Sports Physiology and Performance, 8(2), 195-202. https://doi.org/10.1123/ijspp.8.2.195

Seidman, I. (2006). Interviewing as qualitative research: A guide for researchers in education and the social sciences. New York: Teachers college

Siregar, N.S. and Dani, D.P.L. (2019). Hubungan tingkat kecukupan energi dengan status gizi atlet gulat PPLP Sumatera Utara [Relationship between the level of energy sufficiency and the nutritional status among wrestling athletes of PPLP North Sumatra ]. Sains Olahraga: Jurnal Ilmiah Ilmu Keolahragaan, 2(1), 10-18. https://doi.org/10.24114/so.v2i1.12871

Wiersma, L.D. and Fifer, A.M. (2008). "The schedule has been tough but we think it's worth it": The joys, challenges, and recommendations of youth sport parents. Journal of Leisure Research, 40(4), 505530 .

https:// doi.org/10.1080/00222216.2008.11950150

Wu, E.H. (2008). Parental influence on children's talent development: A case study with three Chinese American families. Journal for the Education of the Gifted, 32(1), 100-129. https://doi.org/10.4219/jeg2008-826

Wuerth, S., Lee, M.J. and Alfermann, D. (2004). Parental involvement and athletes' career in youth sport. Psychology of Sport and Exercise, 5(1), 21-33. https://doi.org/10.1016/S1469-0292(02)00047-X 